\title{
Simplified Design Equation of Lap Splice Length in Compression
}

\author{
Sung-Chul Chun, ${ }^{1)}$ Sung-Ho Lee, ${ }^{2)}$ and Bohwan $\mathrm{Oh}^{2)}$
}

\author{
(Received March 16, 2010, Revised May 10, 2010, Accepted May 20, 2010)
}

\begin{abstract}
With the emergence of ultra-high strength of concrete, the compression lap splice has become an important area of interest. According to ACI 318-08, a compression splice can be longer than a tension splice when high-strength concrete is used. By reevaluating the test results of compression splices and performing regression analysis, a simplified design equation for splice length in compression was developed based on the basic form of design equations for development/splice lengths of deformed bars and hooks in tension. A simple linear relation between $l_{s} / d_{b}$ and $f_{s c} \sqrt{f_{c}^{\prime}}$ was assumed, and yields good values for the correlation coefficient and the mean and the $\mathrm{COV}$ (coefficient of variation) of the ratios of tests to predictions of splice strengths in compression. By including the $5 \%$ fractile coefficient of 0.83 , a design equation for splice length in compression was developed. The splice length calculated using the proposed equation has a reliability that is equivalent to other provisions for reinforcing bars.
\end{abstract}

Keywords: compression lap splice, bond, end bearing, transverse reinforcement, specified splice strength.

\section{Introduction}

The compression lap splice criteria in ACI $318-08^{1}$ were based on just 11 column tests ${ }^{2}$ that were conducted more than 40 years ago, using concrete with a maximum compressive strength of 29.0 MPa. Lap requirements for compression splices have remained the same since the 1963 Code. Due to end bearing, the splice length in compression is shorter than the length in tension to develop the specified yield strength of reinforcing bars. However, according to ACI 318-08, a design compression lap splice could be longer than a design tension lap splice as concrete strength becomes higher, as shown in Fig. 1. This anomaly arises because the provisions for compression splices do not properly consider the effects of the compressive strength of the concrete and transverse reinforcement. To enhance the efficiency of high-strength concrete, new criteria for compression lap splices are required. A new design equation ${ }^{3,4}$ for compression splice length was recently suggested but seems too complicated. For practical usage, the design equation of compression splice needs to have a similar form to the equations of development/splice length in tension.

\section{Objectives}

This research reevaluates the test data of fifty-one column specimens to develop a simplified design equation for splice length in compression. Design equations of development and splice lengths

\footnotetext{
${ }^{1)}$ KCI Member, Daewoo Institute of Construction Technology, Suwon 440-210, Korea. E-mail: bluebird@dwconst.co.kr.

${ }^{2)}$ KCI Member, Daewoo Institute of Construction Technology, Suwon 440-210, Korea.

Copyright (c) 2010, Korea Concrete Institute. All rights reserved, including the making of copies without the written permission of the copyright proprietors.
}

in tension and compression were investigated, and a basic form of the simplified equation of compression splice length was developed. Through a regression analysis of the test results based on the basic term of development/splice length in tension, an equation was derived to predict splice strength, which was then converted into an equation for splice length.

\section{Design equations of development and splice lengths}

\subsection{Development and splice in tension}

The lap length in tension of ACI 318-08 is calculated using Eq. (1), which was based on the study of Orangun et al. ${ }^{5}$ For Class A splice, the splice length is equal to the development length, while for Class $\mathrm{B}$ splice, the development length is multiplied by a factor of 1.3 .

$$
l_{s t}=k\left[\frac{f_{y}}{1.1 \lambda \sqrt{f_{c}^{\prime}}} \frac{\psi_{t} \psi_{e} \psi_{s}}{\left(\frac{c_{b}+K_{t r}}{d_{b}}\right)}\right] d_{b} \geq 300 \mathrm{~mm}
$$

where $k$ is 1.3 for Class B splice, $\psi_{t}$ is 1.3 if horizontal reinforcement is placed such that more than $300 \mathrm{~mm}$ of fresh concrete is cast below the splice length, $\psi_{e}$ is 1.5 for epoxy-coated reinforcement with cover less than $3 d_{b}$ or clear spacing less than $6 d_{b}, \psi_{e}$ is 1.2 for all other epoxy-coated reinforcement, $\psi_{s}$ is 0.8 for $19 \mathrm{~mm}$ and smaller bars, $\lambda$ is 0.75 for lightweight concrete, for other cases, $k, \psi_{t}, \psi_{e}, \psi_{s}$, and $\lambda$ are 1.0 ,

Development length in tension terminating in a standard hook is determined from Eq. (2). The equations for development and splice lengths in tension have a basic form regarding $f_{y} \sqrt{f_{c}^{\prime}}$.

$$
l_{d h}=\frac{0.24 \psi_{e} f_{y}}{\lambda \sqrt{f_{c}^{\prime}}} \geq 8 d_{b} \text { and } 150 \mathrm{~mm}
$$




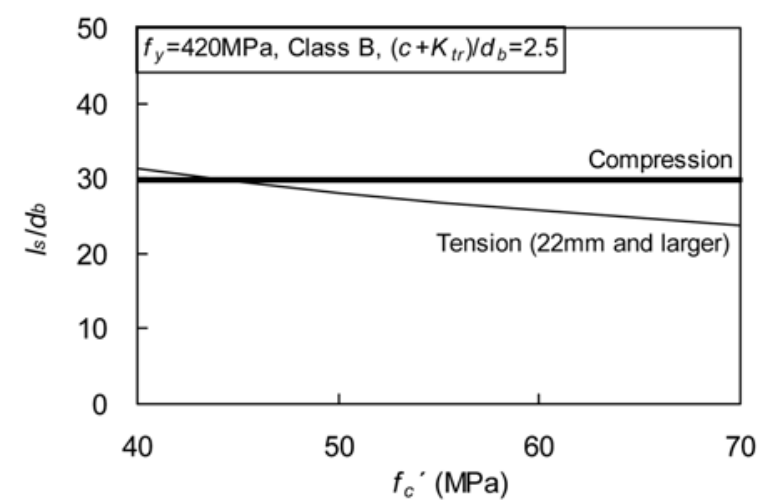

Fig. 1 Comparison of calculated splice lengths by $\mathrm{ACI} 318-08$.

\subsection{Lap splice in compression}

Design codes in the USA ${ }^{1}$, Canada, ${ }^{6}$ and New Zealand ${ }^{7}$ have similar provisions for compression lap splices. Equation (3) is the design equation provided in ACI 318-08 for compression splice lengths.

$$
\begin{aligned}
I_{s c, A C I} & =0.071 f_{y} d_{b} & & \text { for } f_{y} \leq 420 \mathrm{MPa} \\
& =\left(0.13 f_{y}-24\right) d_{b} & & \text { for } f_{y}>420 \mathrm{MPa}
\end{aligned}
$$

The specified yield strength for the bars is considered but the specified compressive strength of the concrete is not included in Eq. (3). Consequently, a compression lap splice could be longer than a tension lap splice, as shown in Fig. 1.

The $f i b$ code ${ }^{8}$ adopted tension splice rules as provisions of compression splices. Compression splice length is obtained from Eq. (4), which is identical to the basic equation for tension splice length. The fib code has two features that distinguish it from the ACI code: (1) it has the same equation as a basic equation of a tension splice length and (2) it accounts for concrete strength. Even though the end bearing contribution is not explicitly expressed in Eq. (4), the design splice in compression is always shorter than the length in tension splices. The effect of the concrete compressive strength in the fib code was derived from studies on tension splices, not on compression splices.

$$
\begin{aligned}
l_{s c, f i b} & =\frac{f_{y} d_{b}}{1.45\left(f_{c}{ }^{\prime 2}\right)^{2 / 3}} \quad \text { for } f_{c}{ }^{\prime} \leq 50 \mathrm{MPa} \\
& =\frac{f_{y} d_{b}}{5.15\left(f_{c}{ }^{\prime}\right)^{1 / 3}} \quad \text { for } f_{c}{ }^{\prime}>50 \mathrm{MPa}
\end{aligned}
$$

Chun et al. ${ }^{3,9}$ tested 76 columns having lap splices with concrete that had a design compressive strength of 40 and $60 \mathrm{MPa}$ to evaluate the effects of concrete strength and transverse reinforcement on the lap splice strength in compression, and proposed ${ }^{4}$ Eq. (5) as a design equation for lap splice in compression through a regression analysis for specimens that failed in splitting.

$$
\frac{l_{s c}}{d_{b}}=\left(\frac{\frac{f_{y}}{0.82 \sqrt{f_{c}^{\prime}}}-16.4-1.8 \delta}{11.1+1.5 \frac{K_{t r}}{d_{b}}}\right)^{2} \leq 0.071 f_{y}
$$

where $f_{c}^{\prime}$ cannot exceed $70 \mathrm{MPa}, K_{t r} / d_{b}$ cannot be greater than 1.76 , and the upper limits are replaced with $\left(0.13 f_{y}-24\right)$ if $f_{y}$ is greater than $420 \mathrm{MPa}$.

Each term of Eq. (5) represents the physical meaning of contribution to splice strength, e.g. 16.4 of the numerator is related to the end bearing strength of lap splices without transverse reinforcement. However, Eq. (5) seems too complex compared with the equations of lap splice length (Eq. (1)) and the development length of standard hooks (Eq. (2)) in tension, because Eq. (5) has a square expression. For practical usage, a simplified design equation of compression splice is required that has a similar form to Eqs. (1) and (2).

\section{Experimental program}

\subsection{Specimen design}

Similarly to previous tests on compression splices, ${ }^{2,10}$ tied columns with a rectangular cross-section with lap splices were concentrically loaded, as shown in Fig. 2. From the survey of the literature, five parameters were selected: the compressive strength of the concrete, clear spacing between bars, splice length, area of transverse reinforcement, and bar diameter.

Two bar diameters, $22 \mathrm{~mm}$ and $29 \mathrm{~mm}$, were chosen, and their design yield strength was $420 \mathrm{MPa}$. The measured yield strength, tensile strength, and modulus of elasticity of the spliced bars are summarized in Table 1. The compressive strengths of the concrete were designed to be 40 and $60 \mathrm{MPa}$, which were higher than the maximum strength used in previous tests. ${ }^{2,10,11}$

Three kinds of clear spacing were used: the minimum clear spacing of $1.5 d_{b}$, as required by ACI 318-08, along with clear spacings of $2.5 d_{b}$ and $3.0 d_{b}$. The splice lengths were designed to be $10 d_{b}, 15 d_{b}$, and $20 d_{b}$. For specimens with a clear spacing of $3.0 d_{b}$, the longest splice of $20 d_{b}$ was omitted because they were expected to fail in the compression yield of the bars before a splice failure.

The area and location of the transverse reinforcement are also main variables. Two kinds of transverse reinforcement placement were used: (1) one hoop was placed at each end of the splice and (2) two hoops were added at a $3.3 d_{b}$ vertical spacing along the splice length. For the confined specimens with transverse rein-

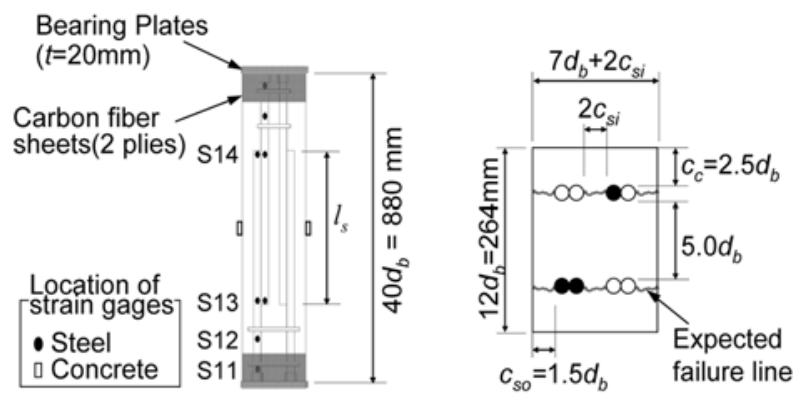

Fig. 2 Details of specimen of unconfined splices.

Table 1 Summary of coupon tests of spliced bars.

\begin{tabular}{c|c|c|c}
\hline $\begin{array}{c}\text { Bar diameter } \\
(\mathrm{mm})\end{array}$ & $\begin{array}{c}\text { Yield strength } \\
(\mathrm{MPa})\end{array}$ & $\begin{array}{c}\text { Tensile strength } \\
(\mathrm{MPa})\end{array}$ & $\begin{array}{c}\text { Modulus of } \\
\text { elasticity }(\mathrm{GPa})\end{array}$ \\
\hline \hline 22 & 513.5 & 617.6 & 183.9 \\
\hline 29 & 471.4 & 601.9 & 189.4 \\
\hline
\end{tabular}


forcement (denoted as confined specimens hereinafter), the splice lengths were fixed as $10 d_{b}$, because a splice length longer than $10 d_{b}$ was expected to cause the bars to yield before a splice failure. Each specimen had a duplicate, and a total of 76 columns were tested. The ranges of the parameters of tested columns are summarized in Table 2.

The details for a typical test specimen are shown in Fig. 2. Splitting cracks were intended to form through the side cover and between the bars, as shown in the horizontal lines of Fig. 2. The front cover thickness of $2.5 d_{b}$ and the distance between the layers of reinforcing bars of $5.0 d_{b}$ were designed so that no unintended cracks would form. Bearing plates with a thickness of $20 \mathrm{~mm}$ were placed at both ends of the specimens. The reinforcing bars were connected to these steel plates via threaded sleeves. The sleeves were welded to the steel plates to ensure that the applied loads were directly transferred to the bars without development lengths. The specimen height of $40 d_{b}$ was selected. To prevent local failure at the ends, the specimens were wrapped at the ends with 2-ply carbon fiber sheet, as shown in Fig. 2.

A monotonic axial load was applied to each specimen using a hydraulic jack with a capacity of 5,000 kN, as shown in Fig. 3 . Concentrically loaded columns provided severe conditions for lap splices compared with flexural members having a strain gradient. The specimens were designed to be short so that a splitting failure occurred within the splice length. To find the end bearing and the bond contributions, electrical resistance strain gauges were attached to four points on each bar as shown in Fig. 2. The gauges were mounted at a distance of $1 d_{b}$ from the end of one bar, and at the same level of the other spliced bar.

\subsection{Test results}

All of the specimens failed in a brittle and sudden manner, and in particular, the cover concrete spalled explosively, as shown in Fig. 4(a). Typical splitting failures of the specimens are shown in Fig. 4. The failure modes can be classified into three types: splitting, compression, and premature failure.

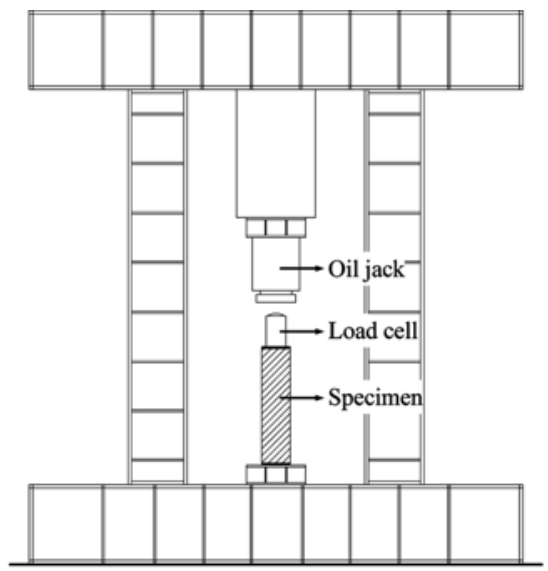

Fig. 3 Test setup.
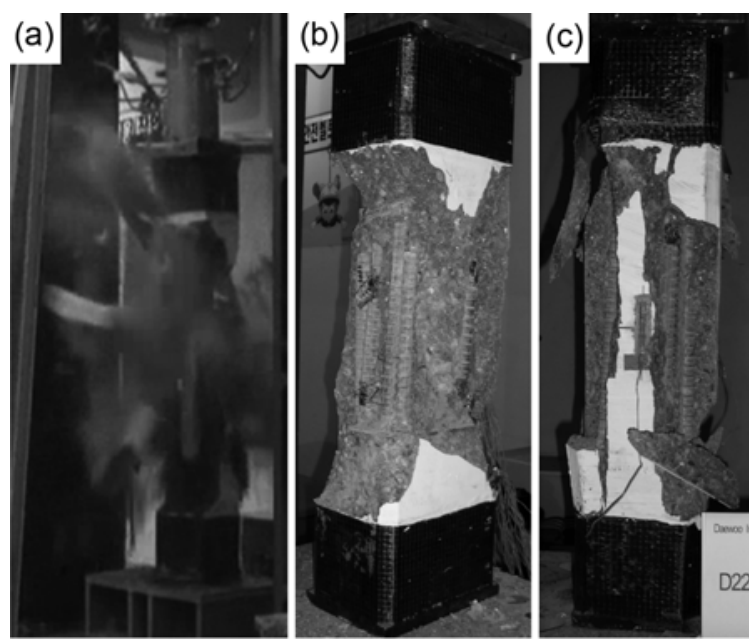

Fig. 4 Typical specimen failures: (a) Explosive spalling of concrete cover, (b) fully splitting, and (c) partially splitting.

The cover concrete spalled and immediately failed because of a transversely bursting force exerted by bond and end bearing. This kind of failure was defined as a splitting failure. Cases in which splitting occurred in all splices simultaneously were called "full splitting failure." If some splices failed to split even though the axial strains on all of the spliced bars were similar, it was described as a "partial splitting failure." Material and geometric imperfections in the actual columns were unavoidable, and therefore partial splitting failure was considered to be the normal failure mode.

In cases in which the splice strengths were sufficient, a compression failure would occur in a column. Premature failure was a local failure resulting from an eccentricity, or a local failure out of the splice region. As the data obtained from specimens in compression and premature failures were not related to the strength of the compression splices, these data are excluded in the analysis of the test results.

The splice strengths were determined using the measured strains on spliced bars based on the stress-strain response of the coupon tests. As the splice length became longer and the transverse reinforcement index $\left(K_{t r} / d_{b}\right)$ increased, the splice strength $\left(f_{s c, e}\right)$ increased.

The bar stresses developed by end bearing $\left(f_{\text {brg,e }}\right)$ were determined from the measured strains at S14 in Fig. 2. The normalized bar stresses were found to be nearly constant regardless of variations in splice length, clear spacing, and bar diameter. The mean value of the stresses developed by end bearing was $16.4 \sqrt{f_{c}{ }^{\prime}} \mathrm{MPa}$, which was about one-third the design yield strengths of the bars. For confined splices, the stresses developed by end bearing were found to be unrelated to $K_{t r}$ and to be improved by the transverse reinforcement placed at the ends only. The mean value of the stresses developed by end bearing was $18.2 \sqrt{f_{c}^{\prime}} \mathrm{MPa}$.

The bond contributions $\left(f_{b, e}\right)$ to the splice strengths were obtained by deducting the stresses developed by the end bearing

Table 2 Summary of test matrix of References 3 and 9.

\begin{tabular}{c|c|c|c|c|c|c}
\hline Test series & $\begin{array}{c}\text { No. of } \\
\text { specimens }\end{array}$ & $\begin{array}{c}\text { Concrete compressive } \\
\text { strength } f_{c}^{\prime}(\mathrm{MPa})\end{array}$ & $\begin{array}{c}\text { Normalized lap } \\
\text { length } l_{s} / d_{b}\end{array}$ & $\begin{array}{c}\text { Bar diameter } d_{b} \\
(\mathrm{~mm})\end{array}$ & $\begin{array}{c}\text { Transverse reinforce- } \\
\text { ment index } K_{t r} / d_{b}\end{array}$ & $\begin{array}{c}\text { Clear spacing index } \\
c_{s i} / d_{b}\end{array}$ \\
\hline \hline Unconfined tests & 44 & 48.9 to 73.7 & $10,15,20$ & 22,29 & - & $0.75,1.25,1.5$ \\
\hline Confined tests & 32 & 48.9 to 73.7 & 10 & 22,29 & $0.34,0.59,1.01,1.76$, & $0.75,1.25,1.5$ \\
\hline
\end{tabular}


from the splice strengths. The bar stress developed by the bond increased as the splice length became longer. However, the stress developed by the bond does not increase proportionally when the splice length is doubled. For confined splices, the bar stress developed by the bond increased as $K_{t r} / d_{b}$ increased. The splice strengths $\left(f_{s c, e}\right)$ and the stresses developed by bond $\left(f_{b, e}\right)$ and end bearing $\left(f_{\text {brg,e }}\right)$ of each specimen were reported in References 3 and 9.

\section{Simplified model for lap splice in compression}

The experimental results were used to develop a simplified model for predicting splice strength, and finally to determine the splice length in compression.

\subsection{Average strength of lap splice in compression}

From the parameters affecting splice strength, the ratio of splice length to bar diameter, the concrete strength, and the transverse reinforcement index were selected for a new model because the clear spacing was found to have no relation to splice strength. For the sake of simplicity, the splice strength was assumed to be proportional to $\sqrt{f_{c}^{\prime}}$. Figure 5 shows the splice strengths and the end bearing strengths of specimens without transverse reinforcement (denoted as unconfined specimens hereinafter). As shown in the lower portion of Fig. 5, the contribution of end bearing was not related to the splice length.

The effect of the splice length is illustrated in Fig. 5 with three equations. The simple linear equation (1) in Fig. 5) has a low slope of 0.863 and a great intercept of $44.9 \sqrt{f_{c}^{\prime}}$ MPa. Equation (1) can be used to represent the characteristic of compression splice that splice strength does not increase proportionally when splice length is doubled. Equation (1) is easily transformed into a design equation for splice length, but may overestimate splice

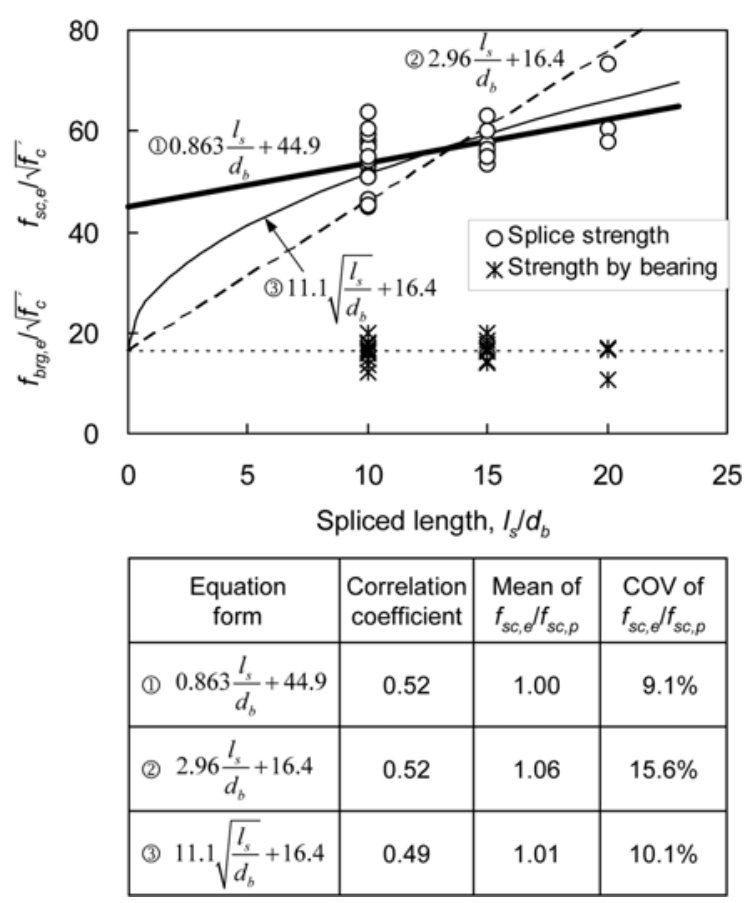

Fig. 5 Splice length vs. splice strength relationship of unconfined specimens. strength when splice length is short. The value of $44.9 \sqrt{f_{c}^{\prime}} \mathrm{MPa}$ was simply obtained through regression analysis, and does not represent any physical meaning, e.g. the strength of a splice of zero length nor the strength developed by end bearing. Equation (2) adopts the fixed intercept of $16.4 \sqrt{f_{c}^{\prime}} \mathrm{MPa}$, which is a mean value for the measured stresses developed by end bearing. The slope of equation (2) is so steep that it may overestimate the strength of splices with longer length. The square root of $l_{s} / d_{b}$ is used in equation (3), and it can be explicitly perceived that the splice strength is not linearly proportional to the splice length. However, equation (3) provides an equation for design lap length in compression that is much too complex, as seen in Eq. (5).

Correlation coefficients between tests and predictions, and average values and coefficients of variation (COV) of the ratios of tests to predictions are summarized in Fig. 5 for each equation for 30 unconfined specimens. Equation (1) gives the best values for all three items, and equation (1) is selected to predict the mean strengths of compression splices $f_{\text {sc,p,uncon }}$.

$$
f_{\text {sc }, p, \text { uncon }}=\left(0.863 \frac{l_{s}}{d_{b}}+44.9\right) \sqrt{f_{c}^{\prime}}
$$

The compression splice strength with transverse reinforcement can be obtained by adding the contribution of transverse reinforcement to the splice strength of unconfined splices. The increments of confined splices are shown in Fig. 6 compared with predictions made using Eq. (6) with varying $K_{t r} / d_{b}$. As more transverse reinforcement was provided, higher splice strength was achieved. The splice strength increases in proportion to the amount of transverse reinforcement within $K_{t r} / d_{b} \leq 1.76$. A linear regression analysis was carried out with 21 specimens, and provided the modification factor for confined splices as $\psi_{s c}=\left(1+0.084 K_{t r} / d_{b}\right)$. Finally, an equation for predicting the mean strengths of compression splices can be expressed as Eq. (7).

$$
\begin{aligned}
& f_{s c, p}=\psi_{s c}\left(0.863 \frac{l_{s}}{d_{b}}+44.9\right) \sqrt{f_{c}{ }^{\prime}} \\
& \text { where } \psi_{s c}=1+0.084 \frac{K_{t r}}{d_{b}}
\end{aligned}
$$

The splice strengths predicted using Eq. (7) were compared to

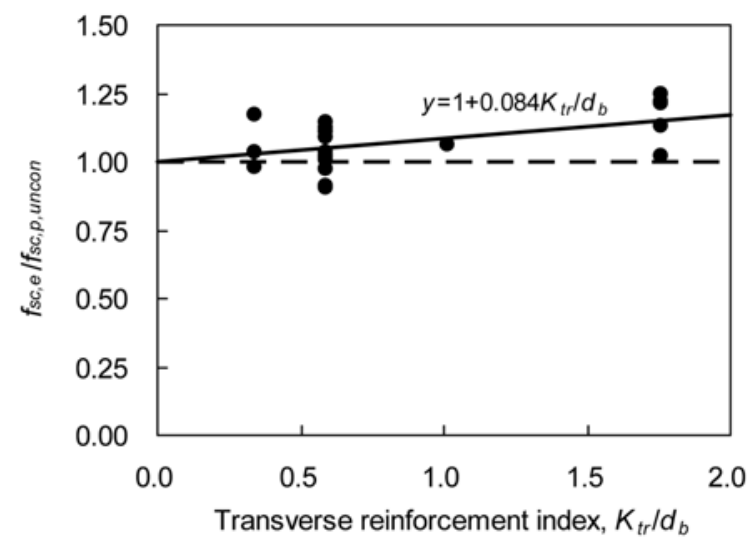

Fig. 6 Splice strength increment with $K_{t r} / d_{b}$. 


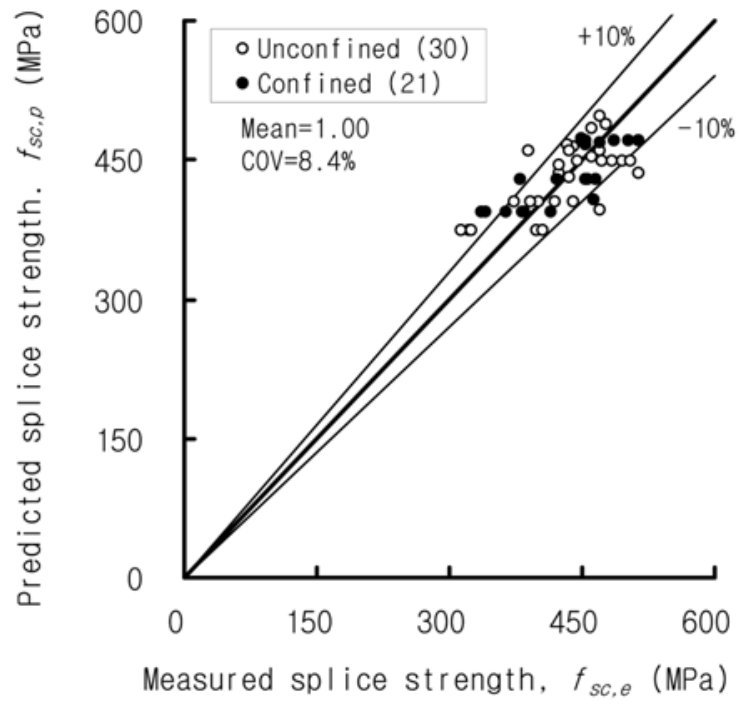

Fig. 7 Comparison of test results and predicted values (Note: ( ) = number of tests)

the test values for 51 specimens in Fig. 7, which shows that the splice strengths can be predicted regardless of whether transverse reinforcement is present or not. The coefficient of variation (COV) for the ratios of test to predicted values is only $8.4 \%$, and the average value of the ratios is 1.00 .

\subsection{Design equation of lap splice in compression}

Splices should have a strength equivalent to the reinforcing bars, which means that the nominal strength of a splice must not be less than the specified design yield strength of the reinforcing bars, with equal or greater ${ }^{12}$ reliability than the bars. ISO $6935-2^{13}$ requires that all of the properties of ribbed bars should be inspected with a $5 \%$ fractile concept. In this study, a $5 \%$ fractile $^{14}$ coefficient $n_{5 \%}$ was used to determine the design strength $\left(f_{s c, d}\right)$ of a compression splice from the mean strength $\left(f_{s c, p}\right)$. A value of 0.83 was determined for $n_{5 \%}$ using the COV of $8.4 \%$ and the number of tests.

For design purposes, it is desirable to determine splice length rather than splice strength. The current equation of ACI 318-08 (Eq. (3)) can be adopted as the upper limit of splice length because it has been practically justified for normal-strength concrete. Equation (7) can be solved for $l_{s}$ by incorporating the $n_{5 \%}$ of 0.83 ,

$$
\frac{l_{s}}{d_{b}}=\frac{1.4 f_{y}}{\psi_{s c} \sqrt{f_{c}^{\prime}}}-52 \leq 0.071 f_{y}
$$

where the upper limits are replaced with $\left(0.13 f_{y}-24\right)$ if $f_{y}$ is greater than $420 \mathrm{MPa}$.

The splice lengths given by Eq. (8) are compared with the lengths given by Eq. (5) and ACI 318-08 in Fig. 8. The proposed equation provides a little longer splice lengths than those by Eq. (5) and can remove the anomaly that a design compression lap splice can be longer than a design tension lap splice. In addition, the data of tests, which gave splice strengths higher than a specified yield strength of reinforcement of $420 \mathrm{MPa}$, are also shown in Fig. 8. From a comparison of these data and the proposed splice lengths, it is found that the proposed equation has a sufficient margin of safety.
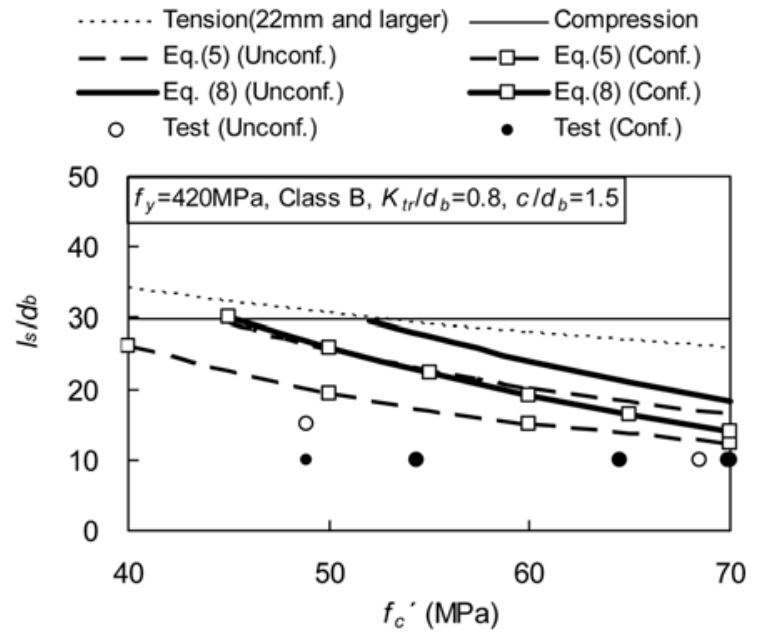

Fig. 8 Splice lengths by $\mathrm{ACl} 318-08$ and by proposed equations.

\section{Design example}

To illustrate the proposed equations, required splice lengths of an example column are calculated. Material and geometric properties of an example column are shown in Fig. 9. The value of $K_{t r} / d_{b}$ is obtained as follows:

$$
\frac{K_{t r}}{d_{b}}=\frac{40 A_{t r}}{s_{t r} n d_{b}}=\frac{40 \times 3 \times 129}{300 \times 5 \times 29}=0.356
$$

The required splice length in compression is calculated using Eq. (5).

$$
\begin{aligned}
l_{s} & =\left(\frac{\frac{400}{0.82 \sqrt{60}}-16.4-1.8 \times 0}{11.1+1.5 \times 0.356}\right)^{2} \times 29 \\
& =465 \mathrm{~mm} \leq 0.071 \times 400 \times 29=824 \mathrm{~mm}
\end{aligned}
$$

The splice length is reduced by $43 \%$ compared to the length calculated by the equation of ACI 318-08 (Eq. (3)). The simplified equation of Eq. (8) yields the length as:

$$
\begin{aligned}
l_{s} & =\left[\frac{1.4 \times 400}{(1+0.084 \times 0.356) \times \sqrt{60}}-52\right] \times 29 \\
& =528 \mathrm{~mm} \leq 0.071 \times 400 \times 29=824 \mathrm{~mm}
\end{aligned}
$$

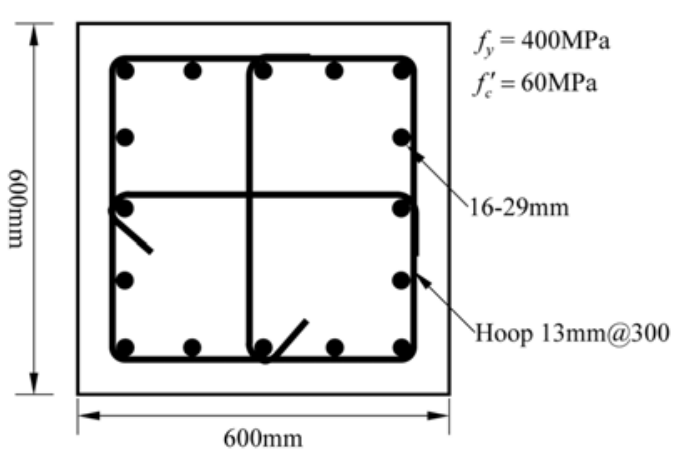

Fig. 9 Section of an example column. 
The simplified equation of Eq. (8) gives a longer splice length by $13.5 \%$ compared to the length using Eq. (5).

\section{Conclusions}

A compression splice can be longer than a tension splice, when observing ACI 318-08 with high-strength concrete. By reevaluating the test results of compression splices and performing a regression analysis, a simplified design equation was developed for splice length in compression. The following conclusions can be drawn.

1) A simple linear relation between $l_{s} / d_{b}$ and $f_{s c} / \sqrt{f_{c}^{\prime}}$ yields better values for the correlation coefficient, the mean and the COV (coefficient of variation) of ratios of tests to predictions of splice strengths in compression, compared with an equation using square root of $l_{s} / d_{b}$.

2) By including the $5 \%$ fractile coefficient of 0.83 , a design equation of splice length in compression was developed. The splice length calculated using the proposed equation has a reliability that is equivalent to other provisions for reinforcing bars.

3) The simplified design equation has a term of $f_{y} / \sqrt{f_{c}^{\prime}}$, which is also used in design equations of development and splice in tension. Consequently, a rational splice length in compression can be easily determined with the proposed equation.

\section{Acknowledgments}

The work presented in this paper was funded by Center for Concrete Corea (05-CCT-D11), supported by Korea Institute of Construction and Transportation Technology Evaluation and Planning (KICTTEP) under the Ministry of Land, Transport and Maritime Affairs of Korean government. The authors would like to thank Prof. Oan-Chul Choi at Soongsil University for his helpful comments and suggestions.

\section{Notations}

\begin{tabular}{|c|c|}
\hline$A_{t r}$ & $\begin{array}{l}=\text { area of transverse reinforcement within spacing } s_{t r} \text { that } \\
\text { crosses the splitting plane }\end{array}$ \\
\hline$c_{b}$ & $\begin{aligned}= & \text { smaller of the minimum concrete cover or } 1 / 2 \text { of the } \\
& \text { clear spacing between bars }\end{aligned}$ \\
\hline$d_{b}$ & $=$ bar diameter \\
\hline$f_{c}^{\prime}$ & $=$ compressive strength of concrete \\
\hline$f_{\text {sc,p,uncon }}$ & $=$ predicted strength of a unconfined compression splice \\
\hline$f_{s c, p}$ & $=$ predicted strength of a compression splice \\
\hline$f_{y}$ & $=$ specified yield strength of a reinforcing bar \\
\hline$k$ & $=$ factor for splice class of ACI $318-08$ \\
\hline$K_{t r}$ & $\begin{aligned}= & \text { transverse reinforcement index of ACI 318-08 } \\
& \left(=\left(40 A_{t r}\right) /\left(s_{t r} n\right)\right)\end{aligned}$ \\
\hline$l_{d h}$ & $\begin{array}{l}=\text { development length in tension of a deformed bar with } \\
\text { standard hook }\end{array}$ \\
\hline$l_{s c, A C I}$ & $=$ compression splice length calculated by ACI $318-08$ \\
\hline$l_{s c, f i b}$ & $=$ compression splice length calculated by $f i b$ code \\
\hline$l_{s t}$ & $=$ lap splice length in tension of ACI 318-08 \\
\hline$n$ & $=$ number of spliced bars \\
\hline
\end{tabular}

$$
\begin{aligned}
& s_{t r} \quad=\text { spacing of transverse reinforcement } \\
& \delta \quad=1 \text { (one) if transverse reinforcement is placed at ends or } \\
& 0 \text { (zero) if not in Eq. (5) } \\
& \lambda=\text { modification factor reflecting the reduced mechanical } \\
& \text { properties of lightweight concrete }
\end{aligned}
$$

\section{References}

1. ACI Committee 318, Building Code Requirements for Structural Concrete (ACI 318-08) and Commentary, American Concrete Institute, Farmington Hills, Mich., 2008, 465 pp.

2. Pfister, J. F. and Mattock, A. H., "High Strength Bars as Concrete Reinforcement, Part 5: Lapped Splices in Concentrically Loaded Columns," Journal, PCA Research and Development Laboratories, Vol. 5, No. 2, 1963, pp. 27 40.

3. Chun, S. C., Lee, S. H., and Oh, B., "Compression Lap Splice in Unconfined Concrete of 40 and $60 \mathrm{MPa}$ Compressive Strengths," ACI Structural Journal, Vol. 107, No. 2, 2010, pp. $170 \sim 178$.

4. Chun, S. C., Lee, S. H., and Oh, B., "Compression Lap Splice Length in Concrete of Compressive Strength from 40 to $70 \mathrm{MPa}$ (in Korean)," Journal of the KCI, Vol. 21, No. 4, 2009, pp. 401 408.

5. Orangun, C. O., Jirsa, J. O., and Breen, J. E., "A Reevaluation of Test Data on Development Length and Splices," ACI Journal, Vol. 74, No. 3, 1977, pp. 114 122.

6. Canadian Standard Associate, CSA A23.3-04, Design of Concrete Structures, Ontario, Canada, 2004, 214 pp.

7. New Zealand Standard, Concrete Structures Standard, Wellington, New Zealand, 2006.

8. CEB-FIP, FIP Recommendations; Practical Design of Structural Concrete, 1999, 113 pp.

9. Chun, S. C., Lee, S. H., and Oh, B., "Behavior and Capacity of Compression Lap Splice in Confined Concrete with Compressive Strength of 40 and $60 \mathrm{MPa}$ (in Korean)," Journal of the KCI, Vol. 21, No. 4, 2009, pp. 389 400.

10. Cairns, J. and Arthur, P. D., "Strength of Lapped Splices in Reinforced Concrete Columns," ACI Journal, Proceedings, Vol. 76, No. 2, 1979, pp. 277 296.

11. Cairns, J., "Strength of Compression Splices: A Reevaluation of Test Data," ACI Journal, Proceedings, Vol. 82, No. 4, 1985, pp. 510 516.

12. Darwin, D., Idun, E. K., Zuo, J., and Tholen, M. L., "Reliability-Based Strength Reduction Factor for Bond," ACI Structural Journal, Vol. 95, No. 4, 1998, pp. 434 443.

13. ISO 6935-2, Steel for the Reinforcement of Concrete - Part 2: Ribbed Bars-Second Edition, 2007, 20 pp.

14. Natrella, M. G., Experimental Statistics, National Bureau of Standards Handbook 91, United States Department of Commerce, 1966. 